Francisco State University; Michael Lipsky, MIT; Sandy Maisel, Colby College; Judith Stiehm, Florida International University; and Ronald Walters, Howard University.

Continuing their 1988-90 terms are: Christopher Achen, University of Chicago; Kathleen Frankovic, CBS News; Peter A. Gourevitch, University of California, San Diego; Ted Robert Gurr, University of Maryland, College Park; Ronald Kahn, Oberlin College; Barbara J. Nelson, University of Minnesota; Adolph Reed, Jr., Yale University; and Donald Searing, University of North Carolina.

\section{Nominating Committee Welcomes Suggestions}

APSA's Nominating Committee, chaired by Robert Keohane, Harvard University, seeks suggestions for nominees to APSA offices.

The Committee will make nominations for eight Council persons, as well as the offices of secretary, vice presidents (three positions) and president-elect. The Committee will meet in February in Washington and report to the President no later than April 15.

Members of the nominating committee are:

Lucius J. Barker, Department of Political Science, Washington University, St. Louis, MO 63130

Bernard C. Cohen, Vice Chancellor for Academic Affairs, University of WisconsinMadison, Bascom Hall, 500 Lincoln Drive, Madison, WI 53706

Stephen Holmes, Department of Political Science, University of Chicago, 5828 South University Avenue, Chicago, IL 60637

Robert Keohane, Department of Government, Harvard University, Cambridge, MA 02138

Dale Rogers Marshall, Dean of the College, Wellesley College, Wellesley, MA 02138

Kay Schlozman, Department of Political

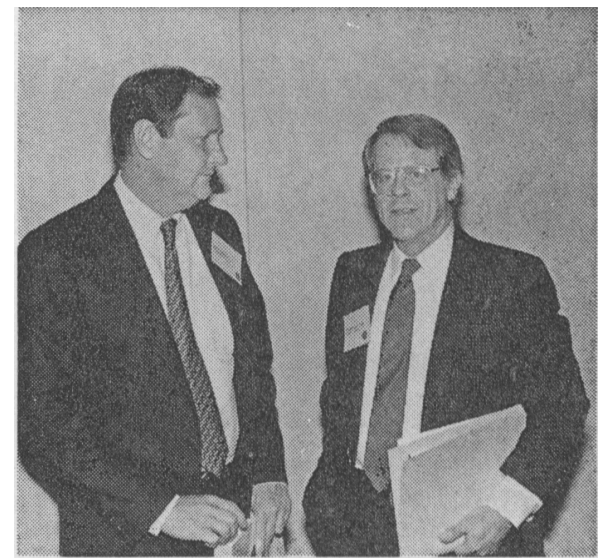

Theodore J. Lowi (r.) and David Brady participated in a program marking the Bicentennial of the U.S. Congress. The symposium was sponsored by the Council of Scholars of the Library of Congress.

Science, Boston College, Chestnut Hill, MA 02167-3807

\section{APSA Presidents Honored}

Eighteen of APSA's 28 living former presidents attended a dinner September 2 given by outgoing President Lucian W. Pye at the Atlanta annual meeting. This is the first time such an event was planned for former presidents; some had not met before the dinner.

Those attending and the year of their presidency:

Pendleton Herring-1952-53

R. Taylor Cole-1958-59

C. Herman Pritchett-1963-64

Gabriel Almond-1965-66

Karl W. Deutsch-1969-70

Heinz Eulau-1971.72

Robert E. Ward-1972-73

Avery Leiserson-1973-74

Austin Ranney-1974-75

James MacGregor Burns-1975-76

Samuel H. Beer-1976-77

John C. Wahlke-1977.78 


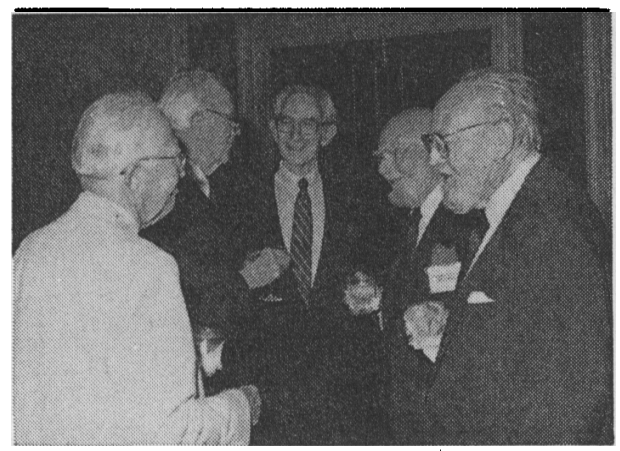

L. to $r$., former APSA Presidents C. Herman Pritchett, R. Taylor Cole, Heinz Eulau and Pendleton Herring share a moment with former APSA Executive Director, Evron Kirkpatrick.

Leon D. Epstein-1978-79

Warren E. Miller-1979-80

Seymour Martin Lipset-1981-82

William H. Riker-1982-83

Aaron Wildavsky-1985-86

Samuel P. Huntington-1986-87

Also attending were President Judith $\mathrm{N}$. Shklar, many spouses, and two former Executive Directors of the Association, Evron M. Kirkpatrick and Thomas E. Mann.

\section{APSA Annual Meeting Placement Service Continues to Grow}

No matter how much space is set aside for the Annual Meeting Placement Service in recent years, it never seems to be enough. The Atlanta Placement Service registered significant increases in the number of employers using the service, and the number of positions available. The decline in the number of applicants may be an early indication of changing market conditions in academia, or it may simply reflect the decline in applicant numbers that takes place when the Annual Meeting is held outside of Washington, D.C.
Annual Meeting Placement Services, 1986-89

\begin{tabular}{lrrrr}
\hline & 1986 & 1987 & 1988 & 1989 \\
\hline f Employers & 127 & 143 & 161 & 179 \\
f Applicants & 487 & 423 & 545 & 483 \\
f Positions & 213 & 227 & 252 & 282 \\
Other* & 6 & 9 & 4 & 15 \\
\hline
\end{tabular}

* Refers to listings with an unspecified number of vacancies.

\section{The End of Realignment?}

\section{Carol Nechemias \\ Pennsylvania State University-Harrisburg}

Chaired by Professor Harold F. Bass, Jr., of Ouachita Baptist University, the 1989 Harold Lasswell Symposium focused on a household word within our professionthe concept of realignment. Although all the papers, presented, respectively, by Professor Joel H. Silbey of Cornell University, Professor Everett Carll Ladd of the University of Connecticut and the Roper Center for Public Opinion Research,' and Professor Byron E. Shafer of Nuffield College (Oxford University), attacked the utility of realignment, their critiques shared little in common other than the view that realignment has obscured more than it clarifies. Faced with this critical onslaught, the discussants, Professor Walter Dean Burnham of the University of Texas, Austin, and Samuel T. McSeveney of Vanderbilt University, provided a counterbalance to what had become a "coroner's inquest."

Silbey presented an alternative approach to periodizations of American electoral history which rely on critical realigning elections. He argued that while significant changes have occurred in the American political universe, these changes were not necessarily coterminous with realigning elections. Characterizing the first 50 years under the Constitution as ones of a "volatile non-party system"' Silbey noted that the 1828 election could not be labelled a realigning election. He pointed out that 